\title{
STRATEGI PERCEPATAN FUNGSIONALISASI SENTRA KELAUTAN PERIKANAN TERPADU NATUNA
}

\author{
Strategy to Accelerate the Functionalization of Natuna Integrated Fisheries Marine \\ Center \\ Oleh: \\ Tri Wiji Nurani ${ }^{1}$, Wawan Oktariza ${ }^{2}$, Taryono ${ }^{3}$, Wini Trilaksani ${ }^{4}$, Luky Adrianto ${ }^{5}$, \\ Mubariq Ahmad6, Umi Muawanah7, Christy Desta Pratama ${ }^{8}$

\begin{abstract}
1Dosen pada Departemen Pemanfaatan Sumberdaya Perikanan, FPIK-IPB, triwiji@hotmail.com 2Dosen pada Departemen Pemanfaatan Sumberdaya Perikanan, FPIK-IPB, wawanok@apps.ipb.ac.id

${ }^{3}$ Dosen pada Departemen Manajemen Sumberdaya Perairan, FPIK-IPB, taryono@apps.ipb.ac.id

${ }^{4}$ Dosen pada Departemen Teknologi Hasil Perairan, FPIK-IPB, wtrilaksani@apps.ipb.ac.id

5Dosen pada Departemen Manajemen Sumberdaya Perairan, FPIK-IPB, lukyadrianto@apps.ipb.ac.id ${ }^{6}$ Conservation Strategy Fund, Indonesia, mubariq@conservation-strategy.org ${ }^{8}$ Conservation Strategy Fund, Indonesia, desta@conservation-strategy.org
\end{abstract} \\ ${ }^{7}$ Balai Besar Riset Sosial Ekonomi Kelautan dan Perikanan, BRSDM-KP, KKP, umi.muawanah@gmail.com
}

*Korespondensi: triwiji@hotmail.com

Diterima: 16 September 2020; Disetujui: 18 April 2021

\begin{abstract}
The Indonesian government has issued Presidential Instruction No. 7/2016 aiming at accelerating the development of the fisheries sector. Natuna is one of the locations designated as the Integrated Fisheries Marine Center (SKPT). The purpose of the study was to develop a strategy for accelerating the functionalization of the Natuna SKPT. The study began with a situational analysis of the existence of the Natuna SKPT in order to identify opportunities and challenges, followed by providing recommendations for strategic steps to accelerate the functionalization of the Natuna SKPT. This research has identified opportunities and problems to accelerate the functionalization of the Natuna SKPT, namely the potential for pelagic and demersal fish resources that have great opportunities to be utilized and opportunities to export fresh products for demersal fish. However, there are some problems, namely, the fishing business is a small-scale business with poor knowledge and skills support from fishermen, fish landing sites are scattered in several locations, limited availability of ice for fishing, fish processing businesses are still on a household scale and limited to traditional preparations, limited labor capacity, high cost of packaging, and limited accessibility for marketing. Strategic steps that can be taken are optimizing the utilization of pelagic and demersal fish resources through improving the skills of fishermen, increasing fishing fleets controlled by licensing and data collection, and the need for integrated planning for the development of fishing, processing and marketing industries.
\end{abstract}

Keywords: SKPT functionalization, Natuna, opportunity, problems, strategy.

\section{ABSTRAK}

Pemerintah Indonesia telah mengeluarkan Inpres No.7/2016 yang ditujukan untuk percepatan pembangunan sektor perikanan. Natuna merupakan salah satu lokasi yang ditetapkan sebagai Sentra Kelautan Perikanan Terpadu (SKPT). Tujuan penelitian adalah menyusun strategi bagi percepatan fungsionalisasi SKPT Natuna. Kajian diawali melalui analisis situasi terhadap 
keberadaaan SKPT Natuna untuk dapat mengidentifikasi peluang dan tantangan, dilanjutkan dengan memberikan rekomendasi langkah-langkah strategis bagi percepatan fungsionalisasi SKPT Natuna. Hasil penelitian dapat diidentifikasi peluang dan permasalahan untuk percepatan fungsionalisi SKPT Natuna, yaitu potensi sumberdaya ikan pelagis dan demersal memiliki peluang besar untuk dimanfaatkan dan adanya peluang ekspor produk segar untuk ikan demersal. Permasalahan yang dihadapi diantaranya yaitu, usaha penangkapan ikan merupakan usaha skala kecil dengan pengetahuan dan keterampilan nelayan rendah, tempat pendaratan ikan tersebar di beberapa lokasi, terbatasnya ketersediaan es untuk melaut, usaha pengolahan ikan masih skala rumah tangga dan terbatas pada olahan tradisional, terbatasnya kapasitas tenaga kerja, mahalnya biaya pengemasan, dan terbatasnya aksesibilitas untuk pemasaran. Langkah-langkah strategis yang dapat dilakukan yaitu optimalisasi pemanfaatan sumberdaya ikan pelagis dan demersal melalui peningkatan keterampilan nelayan, peningkatan armada penangkapan yang dikendalikan dengan perizinan dan pendataan, serta perlunya perencanaan secara terintegrasi pengembangan industri penangkapan, pengolahan dan pemasaran.

Kata kunci: fungsionalisasi SKPT, Natuna, peluang, permasalahan, strategi

\section{PENDAHULUAN}

Natuna berada pada posisi yang sangat strategis dari segi ekonomi, pertahanan, dan keamanan, serta politik bagi Indonesia, karena posisinya yang terletak di kawasan Laut Natuna Utara dan jalur pelayaran internasional (Mira et al. 2013; Fauzan et al. 2019). Potensi sumberdaya alam Laut Natuna yang melimpah dan berbatasan langsung dengan Laut Cina Selatan, merupakan daya tarik kuat bagi banyak negara untuk memanfaatkannya dan disini juga banyak terjadi penangkapan ikan ilegal serta pelanggaran batas wilayah (Riyadi dan Sari 2019; Mawanto 2020; Putranto et al. 2020).

Kabupaten Natuna merupakan salah satu wilayah yang memiliki potensi sumberdaya pesisir dan laut yang sangat potensial untuk dikembangkan (Hastuti 2008). Potensi sumberdaya ikan Natuna menurut studi identifikasi sumberdaya kelautan dan perikanan Kepulauan Riau mencapai 504.212,85 ton/tahun. Jenis ikan yang dominan adalah ikan tongkol, yang meliputi tongkol krai (Auxis thazard), tongkol komo (Euthynurus affinis), dan tongkol abu-abu (Thunnus tonggol). Potensi ikan pelagis di Natuna mencapai 327.976 ton/tahun dengan pemanfaatan sebesar 99.037 ton. Pada tahun 2019 produksi ikan di Natuna mencapai 104.879,81 ton (DKP Natuna 2019). Potensi sumberdaya ikan yang besar mendorong masyarakat Natuna menggantungkan hidup sebagai nelayan (Maulana dan Rakhman 2020). Terdapat sekitar 20.571 jiwa penduduk Natuna hidupnya tergantung pada usaha di bidang perikanan (BPS Natuna 2017).

Pemerintah Indonesia telah mengeluarkan Instruksi Presiden Nomor 7 tahun 2016 (Inpres 7/2016) tentang Percepatan
Pembangunan Industri Perikanan Nasional yang ditujukan untuk percepatan pengembangan sektor perikanan dengan maksud untuk mengatasi krisis ekonomi, menciptakan lapangan kerja, mengurangi kemiskinan, dan mendukung industri dalam negeri. Adanya dukungan Inpres $7 / 2016$, dua puluh lokasi strategis telah diidentifikasi menjadi prioritas yang potensial bagi percepatan pengembangan sektor industri perikanan melalui skema Sentra Kelautan dan Perikanan Terpadu (SKPT). Natuna termasuk diantara dua puluh lokasi tersebut. Natuna, terletak di Provinsi Kepulauan Riau, secara strategis diidentifikasi sebagai lokasi untuk posisi kedaulatan perbatasan. Pemerintah dalam hal ini Kementerian Kelautan dan Perikanan (KKP) telah merencanakan investasi dan anggaran yang terperinci untuk pembangunan pelabuhan perikanan beserta dengan fasilitasnya, pengadaan kapal, pembangunan cold storage, dan lainnya.

Pemerintah mulai membangun SKPT Natuna sejak tahun 2015. Bagaimana perkembangan pembangunan SKPT Natuna yang telah dilakukan oleh KKP? Bagaimana operasionalisasi SKPT? Apa permasalahanpermasalahan yang dihadapi? Penelitian ini dilakukan untuk menjawab pertanyaan tersebut, selain itu juga untuk dapat merekomendasikan langkah-langkah strategis upaya percepatan fungsionalisasi SKPT Natuna. Penelitian ini bertujuan untuk (1) mengidentifikasi peluang dan permasalahan operasional SKPT Natuna, dan (2) merekomendasikan langkah-langkah strategis untuk percepatan fungsionalisasi SKPT Natuna. 


\section{METODE}

Pengembangan perikanan merupakan sistem bisnis, yang harus memperhatikan pengembangan kegiatan dari pra produksi, produksi, penanganan pasca produksi, pengolahan hingga distribusi dan pemasaran. Kegiatan perikanan dimulai dari upaya untuk dapat memanfaatkan sumberdaya ikan di suatu perairan melalui proses penangkapan ikan, untuk menghasilkan produksi ikan. Selanjutnya, produksi ikan yang dihasilkan tersebut akan memberikan manfaat bagi para pelaku setelah melalui kegiatan pasca penangkapan, pengolahan ikan dan/atau pemasaran (Gigentika et al. 2017; Syukhriani et al. 2018; Nurani et al. 2018; Anwar 2019).

Secara garis besar pengembangan fungsionalisasi sebuah pelabuhan, yaitu terkait dengan fungsi dan perannya untuk mendukung aktivitas yang ada di dalam lingkup pelabuhan (Hutapea et al. 2017; Hutapea et al. 2019; Reza et al. 2019). Aktivitas di pelabuhan secara garis besar mencakup tiga kegiatan utama yaitu industri penangkapan ikan, industri pengolahan dan pemasaran. Upaya untuk dapat melakukan percepatan fungsionalisasi SKPT Natuna memerlukan sinergi diantara keseluruhan kegiatan yang ada, karena output dari satu kegiatan akan menjadi input bagi kegiatan lainnya. Keterpaduan diperlukan untuk dapat saling mendorong laju perkembangan diantara masing-masing kegiatan. Percepatan pengembangan industri perikanan tangkap diperlukan untuk dapat meningkatkan hasil tangkapan, khususnya bagi wilayah perairan yang masih under exploited seperti Natuna. Hasil tangkapan ini sangat penting sebagai sumber bahan baku bagi industri pengolahan ikan. Berdasarkan pendekatan tersebut di atas, strategi percepatan fungsionalisasi SKPT Natuna mencakup percepatan pengembangan dari 3 kegiatan utama yaitu: 1) industri perikanan tangkap, 2) industri pengolahan ikan, dan 3) pemasaran.
Penelitian dilakukan di Kabupaten Natuna, salah satu lokasi yang ditetapkan sebagai SKPT oleh KKP (Gambar 1). Waktu pelaksanaan penelitian yaitu selama 6 bulan, dimulai dari bulan Maret- Agustus 2017. Observasi dan pengambilan data sekunder dilakukan kembali pada Januari-Februari 2020.

Data yang dikumpulkan dalam penelitian ini meliputi data primer dan data sekunder. Data primer dikumpulkan dengan melalui wawancara mendalam, focus group discussion (FGD), observasi lapang. Secara detail, data primer yang dimaksud disajikan pada Tabel 1. Data sekunder diperoleh dengan melakukan studi pustaka dari berbagai sumber terkait. Pihak yang dilibatkan pada wawancara mendalam dan kegiatan FGD adalah Dinas Kelautan dan Perikanan, nelayan, pedagang pengumpul, pelaku industri perikanan, pelaku industri pengolahan, Bappeda, asosiasi, dan lainnya.

Kegiatan FGD dilakukan untuk dapat memahami secara mendalam, mendiskusikan secara terfokus permasalahan dan solusi yang diinginkan oleh para stakeholder di lokasi studi. Cakupan FGD meliputi kegiatan penangkapan ikan, pengolahan ikan, dan pemasaran. Data dan parameter yang digali pada kegiatan wawancara mendalam dan FGD disajikan pada Tabel 1.

Analisis data dilakukan dengan cara analisis deskriptif, dengan diawali melalui identifikasi terhadap permasalahan dan peluang untuk operasionalisasi dan fungsionalisasi SKPT Natuna berdasarkan pada gambaran dari kondisi terkini perikanan Natuna serta fasilitas dan aktivitas di SKPT Natuna. Hasil dari identifikasi peluang dan permasalahan digunakan untuk menentukan rekomendasi langkah-langkah strategis upaya percepatan fungsionalisasi SKPT yang dilakukan secara deskripsif.

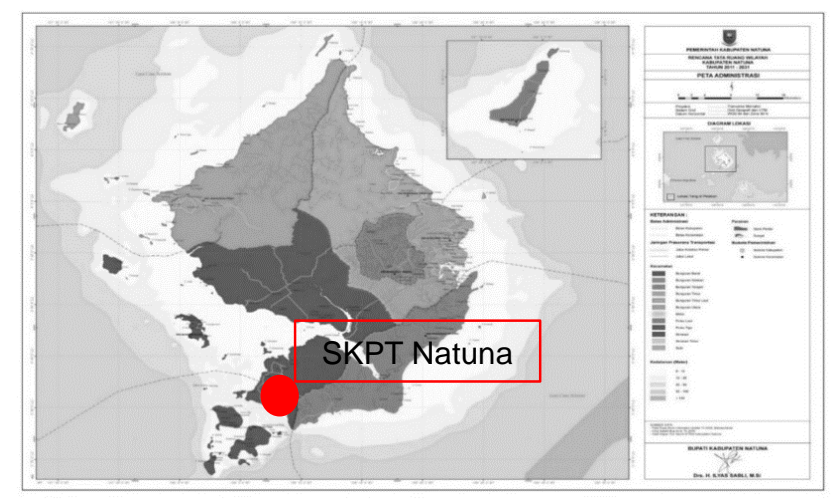

Gambar 1 Peta administrasi Kabupaten Natuna dan Lokasi SKPT Natuna 
Tabel 1 Data dan parameter yang digali pada wawancara mendalam dan FGD

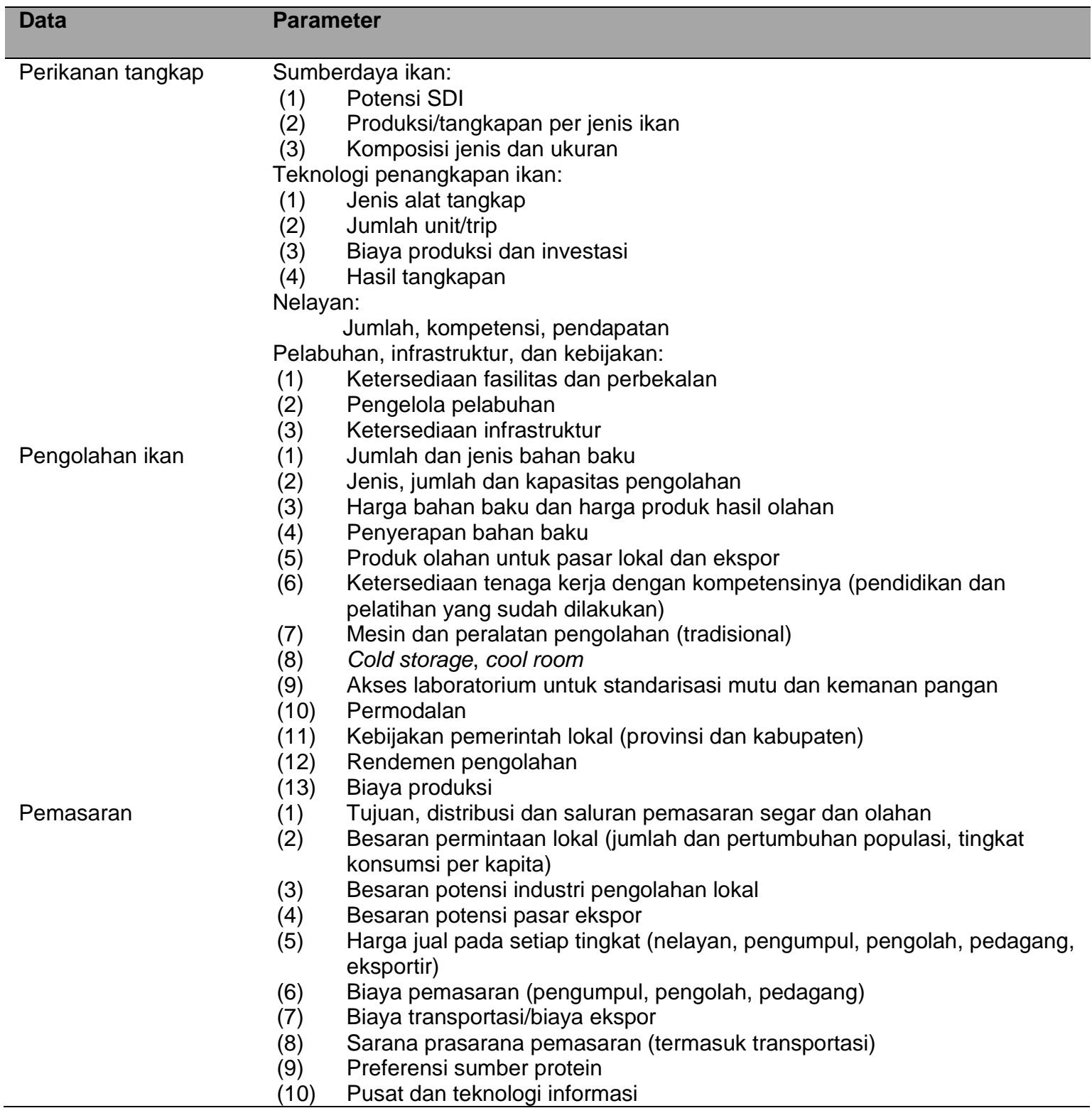

\section{HASIL}

\section{Wilayah Perairan Kabupaten Natuna}

Kabupaten Natuna, dengan ibukota di Ranai merupakan kabupaten baru hasil pemekaran Kabupaten Kepulauan Riau, Provinsi Kepulauan Riau yaitu berdasarkan pada UU Nomor 53 Tahun 1999 Tentang Pembentukan Kabupaten Pelalawan, Kabupaten Rokan Hulu, Kabupaten Rokan Hilir, Kabupaten Siak, Kabupaten Karimun, Kabupaten Natuna, Kabupaten Kuantan Singingi, dan Kota Batam. Secara geografis, Kabupaten Natuna terletak

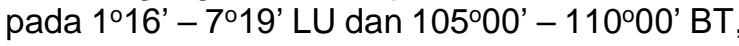
sebelah utara berbatasan dengan Vietnam dan Kamboja, sebelah timur Malaysia bagian Timur (Sarawak) dan Kalimantan Barat, sebelah selatan Kabupaten Bintan, dan sebelah barat Semenanjung Malaysia dan Kabupaten Kepulauan Anambas. Kabupaten Natuna terbagi menjadi dua gugusan pulau yaitu: 1) Gugusan Pulau Natuna, terdiri dari pulaupulau di Bunguran, Sedanau, Midai, Pulau Laut, dan Pulau Tiga; dan 2) Gugusan Pulau Serasan, terdiri dari pulau-pulau di Serasan, Subi Besar dan Subi Kecil (BPS Natuna 2017).

Kabupaten Natuna memiliki topografi yang terdiri dari tanah berbukit dan gunung batu, serta daratan rendah dan landai. Hampir $10 \%$ dari wilayah Kecamatan Bunguran Timur dan Bunguran Barat merupakan daratan rendah dan landai terutama di pinggiran pantai, $65 \%$ berombak dan $25 \%$ 
berbukit sampai bergunung. Ketinggian wilayah antar kecamatan cukup beragam, yaitu berkisar antara 3-959 meter dari permukaan laut dengan kemiringan antara 2-5 meter. Perubahan arah angin sangat mempengaruhi iklim di Kabupaten Natuna. Berdasarkan arah angin, wilayah Natuna dibagi dalam 4 musim yaitu periode Januari - Maret (bertiup angin utara dan timur laut, hujan turun sekali-kali dengan temperatur udara sedang), periode April - Juni (bertiup angin timur laut/tenggara, hujan sedikit dengan temperatur udara agak panas (lebih/kurang $\left.34^{\circ} \mathrm{C}\right)$ ), periode Juli - September (bertiup angin tenggara, hujan turun agak banyak dengan temperatur udara sedang (lebih kurang $\left.30^{\circ} \mathrm{C}\right)$ ), dan periode Oktober - Desember (bertiup angin barat/utara, hujan banyak turun pada bulan September, Oktober dan November, temperatur agak dingin dan lembab pada malam hari). Curah hujan rata-rata berkisar 193,2 mm dengan rata-rata kelembaban udara sekitar $90,4 \%$ dan temperatur sekitar $25,8^{\circ} \mathrm{C}$.

\section{Potensi Sumberdaya dan Kegiatan Perikanan Tangkap}

Potensi sumberdaya ikan Laut Natuna berdasarkan studi identifikasi potensi sumberdaya kelautan dan perikanan Provinsi Kepulauan Riau tahun 2011 yaitu sebesar $504.212,85$ ton per tahun atau sekitar $50 \%$ dari potensi WPP 711 sebesar 1.059.000 ton per tahun dengan jumlah tangkapan yang diperbolehkan (80\% dari potensi lestari) mencapai 403.370 ton. Pada tahun 2015 produksi ikan sebesar 48.699 ton, maka peluang pengembangan perikanan tangkap masih sangat besar (Pusdatin KKP 2016).

Jumlah rumah tangga perikanan (RTP) di Kabupaten Natuna pada tahun 2015 adalah 7066 RTP, yang tersebar pada seluruh kecamatan di Kabupaten Natuna. Sementara itu, produksi ikan mengalami peningkatan dari tahun 2013 hingga tahun 2015. Dibandingkan tahun 2013, produksi pada tahun 2014 mengalami peningkatan sebesar $3,12 \%$. Selanjutnya, apabila dibandingkan dengan tahun 2014, produksi tahun 2015 meningkat sebesar 2,79\% (Dinas Kelautan dan Perikanan Kabupaten Natuna 2019; Pusdatin KKP 2016).

Berdasarkan data Pusdatin KKP (2016), jumlah armada kapal perikanan yang beroperasi di Kabupaten Natuna, pada tahun 2015 sebanyak 4.089 unit kapal dengan pertumbuhan rata-rata dari tahun 2013-2015 sebesar 3,19\% per tahun. Sementara itu menurut data dari DKP Natuna (2019), jumlah kapal pada tahun 2018 berjumlah 3.964 unit dan tahun 2019 berjumlah 4282 unit. Terlihat bahwa jumlah kapal di Natuna tidak mengalami perkembangan jumlah yang signifikan. Jumlah dan ukuran kapal seperti terlihat pada Tabel 2, terlihat bahwa penggunaan perahu tanpa motor, perahu motor tempel dan kapal berukuran <5 GT dominan dengan jumlah sekitar $90 \%$ dari total jumlah armada.

Jumlah alat tangkap yang dioperasikan oleh nelayan lokal terus mengalami peningkatan sejak tahun 2011 hingga tahun 2016. Pada tahun 2011 berjumlah 12725 unit. Jumlah tersebut terus mengalami peningkatan hingga pada tahun 2016 menjadi 20463 unit, dengan rata-rata peningkatan sebesar 8,89\%. Gambar 2 menunjukkan peningkatan jumlah alat tangkap yang dioperasikan oleh nelayan di Kabupaten Natuna pada tahun 2011 hingga tahun 2016.

Jenis alat tangkap yang dominan dioperasikan oleh nelayan di Kabupaten Natuna adalah bubu. Jumlah bubu pada tahun 2011 adalah 5.488 unit, dan jumlah tersebut terus meningkat menjadi 13.660 unit pada tahun 2016. Rata-rata peningkatan jumlah bubu dari tahun 2011 hingga tahun 2016 adalah 18,92\%, dimana peningkatan tertinggi terjadi dari tahun 2015 ke tahun 2016 yaitu sebesar $41,05 \%$. Alat tangkap lainnya yang dominan digunakan oleh nelayan di Kabupaten Natuna adalah pancing ulur. Jumlah pancing ulur pada tahun 2011 adalah 2.958 unit dan meningkat menjadi 3.620 pada tahun 2015. Pada tahun 2016, jumlah pancing ulur tersebut menurun menjadi 3213 unit.

Jenis alat tangkap yang menghasilkan produksi paling banyak adalah pancing ulur. Berdasarkan data Dinas Perikanan Kabupaten Natuna (2012-2017), diketahui bahwa produksi pancing ulur sebanyak $15.315,60$ ton pada tahun 2011 dan mengalami peningkatan menjadi 25.446,96 ton pada tahun 2016. Pancing tonda merupakan jenis alat tangkap yang menghasilkan produksi terbanyak kedua. Pada tahun 2015, produksi pancing tonda sebesar 13234,24 ton. Jumlah tersebut mengalami peningkatan menjadi $15.000,60$ ton pada tahun 2016. Sementara itu, produksi yang dihasilkan oleh nelayan bubu hanya mencapai $3.574,48$ ton pada tahun 2015 dan meningkat menjadi $9.835,20$ ton pada tahun 2016. 
Tabel 2 Jumlah kapal perikanan di Natuna

\begin{tabular}{clcc}
\hline \multirow{2}{*}{ No } & \multirow{2}{*}{ Ukuran } & \multicolumn{2}{c}{ Jumlah (unit) } \\
\cline { 3 - 4 } & & $\mathbf{2 0 1 8}$ & $\mathbf{2 0 1 9}$ \\
\hline 1 & Perahu tanpa motor & 897 & 1061 \\
2 & Motor tempel & 252 & 259 \\
3 & $0-5 \mathrm{GT}$ & 2398 & 2543 \\
4 & $5-10 \mathrm{GT}$ & 382 & 382 \\
5 & $10-20 \mathrm{GT}$ & 25 & 25 \\
6 & $20-30 \mathrm{GT}$ & 4 & 6 \\
7 & $>30 \mathrm{GT}$ & 6 & 6 \\
\hline & Total & 3964 & 4282 \\
\hline
\end{tabular}

Sumber: DKP Natuna 2019

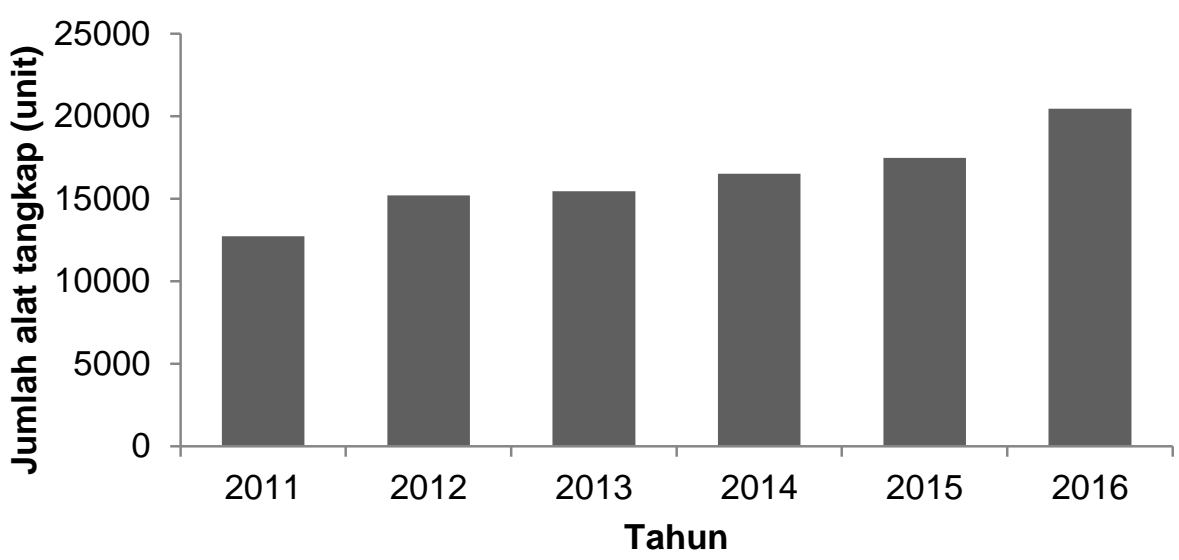

Sumber: Dinas Perikanan Kabupaten Natuna (2012-2017)

Gambar 2 Jumlah alat tangkap di Kabupaten Natuna tahun 2011-2016

\section{Kegiatan Pengolahan Ikan}

Kegiatan pengolahan ikan dan pemasaran di Natuna tergolong prospektif, melihat Natuna sebaga sentra produksi perikanan tangkap dan perikanan budidaya (Nugrohadi et al. 2015). Berdasarkan data Pusdatin KKP (2016) dan Anggraeni et al. (2020), Kabupaten Natuna memiliki beberapa kelompok Pengolah Skala Rumah Tangga (POKLAHSAR) yang tersebar di 9 kecamatan, yaitu Kecamatan Subi, Serasa Timur, Serasan, Pulau Laut, Pulau Tiga, Bunguran Utara, Bunguran Barat, Bunguran Timur, dan Bunguran Selatan. Jumlah kelompok tersebut sebanyak 111 POKLAHSAR, yang terdiri dari kerupuk atom 34 pengolah, kerupuk iris 58 pengolah, fermentasi 32 pengolah, bakso ikan 32 pengolah, dan ikan asin 21 pengolah (Pusdatin KKP 2016; Caraka 2019).

Pada tahun 2014, tercatat jumlah bahan baku pengolahan ikan yang dikelola POKLAHSAR, mencapai $19.095 \mathrm{~kg} /$ bulan atau senilai Rp 166.955.000,-/bulan, sedangkan produksi pengolahan ikan mencapai 73.422 $\mathrm{kg} / \mathrm{tahun}$ atau senilai Rp 4.469.400.000,-/tahun (Ditjen Pengelolaan Ruang Laut 2015 dalam
Pusdatin KKP 2016). Industri pengolahan ikan di Natuna masih terbatas pada skala rumah tangga, dengan nilai tambah yang kecil. Kelemahan lainnya terkait dengan rendahnya kapasitas tenaga kerja di industri pengolahan dan biaya pengemasan produk yang cenderung mahal karena harus didatangkan dari Jakarta.

\section{Pemasaran lkan}

Nelayan di Kabupaten Natuna memiliki kebiasaan untuk mendaratkan dan menjual ikan hasil tangkapannya di dermagadermaga kecil yang tersebar di sepanjang pantai karena lebih dekat dengan fishing base. Sebaran lokasi dan jumlah dermaga di Natuna seperti terlihat pada Tabel 3.

Produksi ikan dari Natuna dipasarkan secara lokal dan beberapa dipasarkan antar daerah atau antar pulau, baik dalam bentuk segar maupun olahan. Tujuan pasar perikanan Natuna yaitu daerah Jakarta, Pemangkat, Tanjung Pinang, Singapore dan Malaysia. Struktur rantai pemasaran produksi ikan dari Natuna melibatkan beberapa 
pelaku, diantaranya yaitu nelayan, pedagang pengum-pul, pedagang pengecer, industri pengolahan ikan.

Pemasaran produk ikan segar khususnya adalah untuk ikan demersal. Harga jual ikan segar utuh ke luar negeri lebih tinggi dibandingkan dengan harga jual olahan ikan secara lokal dan antar daerah atau antar pulau. Hal tersebut menyebabkan pengumpul ikan, khususnya untuk ikan demersal seperti kakap dan anggoli menjual hasil tangkapannya ke pasar luar negeri, terutama ke Singapura dan Malaysia.

Pemasaran hasil pengolahan ikan mengandalkan pendatang yang datang ke Natuna. Aksesibilitas lokasi menjadi salah satu faktor yang menghambat untuk pemasaran ikan dari Natuna ke luar daerah maupun ekspor. Selain itu, harga jual ikan yang ditangkap nelayan juga lebih baik atau lebih tinggi ketika dijual di Pemangkat (Kalimantan), sehingga nelayan yang memiliki fishing base di dekat Pemangkat akan mendaratkan dan menjual hasil tangkapannya ke Pemangkat.

\section{Fasilitas dan Aktivitas di SKPT Natuna}

Pembangunan SKPT Natuna telah dimulai dibangun sejak tahun 2015 dengan persiapan luas lahan pelabuhan seluas 5,8 ha. Pembangunan fasilitas pokok berupa kolam dengan kedalaman $15 \mathrm{~m}$ dan dermaga dengan panjang 120 × 8 m telah dilakukan pada tahun 2015 . Pada tahun 2016 dibangun fasilitas pokok yaitu jalan komplek dan trotoar. Pada tahun ini mulai dibangun fasilitas fungsional yaitu kantor pelabuhan, tempat pelelangan ikan berukuran 20 × 40 m, Integrated Cold Storage (ICS) kapasitas 200 ton, instalasi listrik, penyaluran air bersih, pengisian BBM, pabrik es, fasilitas perbaikan jaring, kios perbekalan dan fasilitas internet, serta fasilitas penunjang kantor koperasi dan fasilitas MCK. Pada tahun 2017 pembangunan kembali untuk fasilitas pokok berupa darmaga berkanopi, tambahan kolam pelabuhan dengan kedalaman $5 \mathrm{~m}$, fasilitas drainase dan causeway. Selain itu juga pembangunan fasilitas fungsional pabrik es dan fasilitas penunjang berupa rumah ibadah, rumah pegawai, pos jaga dan sarana transportasi.

Aktivitas operasional SKPT Natuna dimulai pada pertengahan tahun 2017. Hal ini dapat dilihat dari frekuensi kunjungan kapal bulanan seperti terlihat pada Gambar 3 . Pada awal operasionalisasi SKPT, kunjungan kapal secara umum mengalami peningkatan sampai sekitar bulan Mei 2018. Selama periode tahun 2018 terlihat kegiatan operasional SKPT berjalan dengan baik, dengan jumlah kedatangan kapal yang cukup tinggi yaitu sebesar 3238 kedatangan kapal. Namun operasioanal SKPT menurun di tahun 2019 dengan 1018 kedatangan kapal. Jumlah kedatangan kapal akan berkaitan dengan fungsionalisasi dari fasilitas yang ada di SKPT Natuna.

Jumlah kedatangan kapal berkaitan dengan hasil tangkapan ikan yang didaratkan di SKPT Natuna. Gambar 4 mendeskripsikan produksi dan nilai produksi ikan di SKPT Natuna periode tahun 2017-2019. Selaras dengan jumlah kedatangan kapal, produksi dan nilai produksi ikan di SKPT Natuna juga mengalami peningkatan sejak SKPT Natuna dibuka yaitu dari tahun 2017 sampai dengan tahun 2018. Namun pada tahun 2019, data produksi dan nilai produksi ikan di SKPT Natuna menurun. Diduga ada faktor penghambat yang menjadikan nelayan tidak tertarik untuk mendaratkan ikannya di SKPT Natuna. Salah satu faktor penghambat adalah kebiasaan nelayan untuk mendaratkan ikan dermaga kecil yang tersebar di sekitar Kepulauan Natuna, sulit untuk dipusatkan di SKPT Natuna yang jaraknya cukup jauh.

Tabel 3 Sebaran jumlah dermaga di Natuna

\begin{tabular}{clcc}
\hline No & \multicolumn{1}{c}{ Kecamatan } & Jumlah Desa & Jumlah Dermaga \\
\hline 1 & Serasan & 7 & 10 \\
2 & Midai & 5 & 5 \\
3 & Subi & 8 & 7 \\
4 & Bunguran Timur & 3 & 9 \\
5 & Pulau Laut & 3 & 3 \\
6 & Bunguran Selatan & 4 & 5 \\
7 & Bunguran Timur Laut & 7 & 6 \\
8 & Bunguran Utara & 8 & 10 \\
9 & Bunguran Barat & 9 & 27 \\
10 & Pulau Tiga & 10 & 86 \\
\hline
\end{tabular}




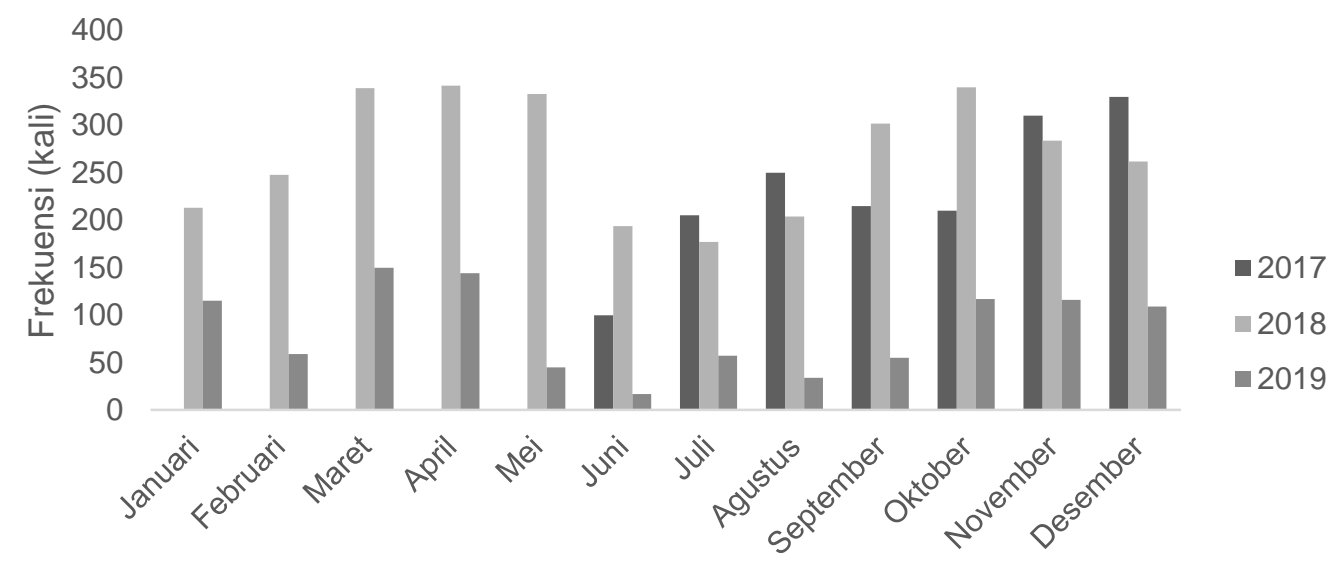

Bulan

Gambar 3 Frekuensi kunjungan kapal periode tahun 2017-2019.

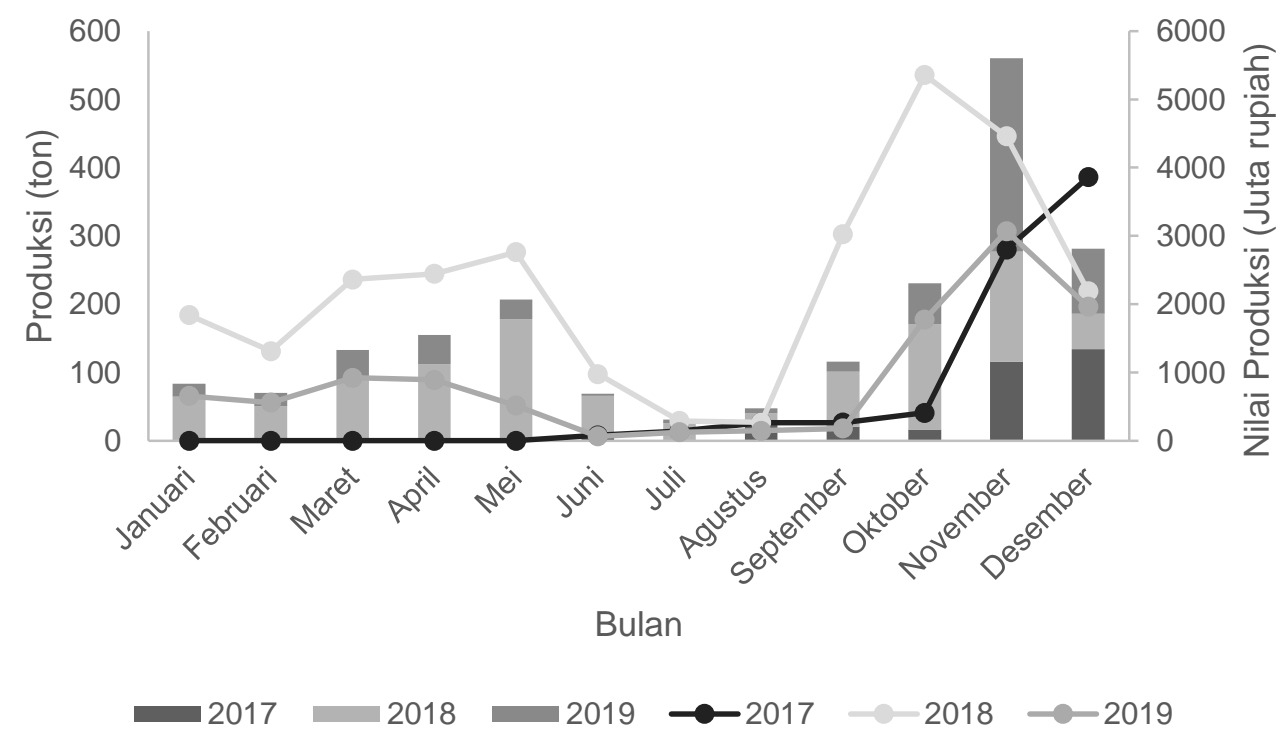

Gambar 4 Produksi dan nilai produksi SKPT Natuna

\section{Peluang dan Permasalahan Perikanan Natuna}

Mengacu pada kondisi eksisting perikanan di Kabupaten Natuna seperti tersebut di atas, maka dapat diidentifikasi peluang dan permasalahan perikanan Natuna yang dapat menjadi faktor pertimbangan bagi upaya percepatan operasionalisasi dan fungsionalisasi SKPT Natuna. Pertama adalah peluang untuk mengoptimalkan pemanfaatan potensi sumberdaya ikan perairan Natuna yang cukup besar, baik untuk ikan pelagis, ikan demersal dan ikan karang. Perairan Natuna memiliki potensi sumberdaya ikan yang termasuk di wilayah pengelolaan perikanan (WPP) 711 (Selat Karimata, Laut Natuna dan Laut Cina Selatan). Disamping itu adanya peluang pasar ekspor untuk produk ikan segar, khususnya ikan demersal ke pasar Singapura dan Malaysia.

Keberadaan SKPT Natuna dengan fasilitas pokok, fungsional dan penunjang yang sudah dibangun dan cukup lengkap, seharusnya dapat mendukung perkembangan perikanan di Natuna. Namun kalau dilihat dari aktivitas kedatangan kapal seperti terlihat pada Gambar 3, dapat dikatakan bahwa operasioanal dan fungsionalisasi SKPT belum berjalan dengan baik. Berbagai kondisi perikanan di Natuna, sepertinya menjadi faktor penghambat bagi fungsionalisasi SKPT Natuna. Faktor penghambat tersebut menjadi suatu permasalahan yang perlu dicarikan solusinya bagi upaya percepatan fungsionalisasi SKPT Natuna. Permasalahan tersebut diantaranya yaitu pertama, pada 
industri perikanan tangkap terlihat bahwa usaha penangkapan ikan merupakan usaha skala kecil, dengan menggunakan kapal berukuran kecil dan teknologi yang sederhana. Seperti telah disebutkan pada Tabel 2, bahwa sekitar $90 \%$ armada penangkapan ikan menggunakan perahu/kapal <5 GT dengan alat tangkap utama bubu dan pancing ulur, serta pengetahuan dan keterampilan nelayan yang terbatas. Jarak jangkau fishing ground nelayan terbatas di pinggir pantai, dan nelayan mendaratkan ikannya di dermaga kecil dekat tempat tinggal mereka. Inilah yang menjadikan tempat pendaratan ikan tersebar di berbagai lokasi. Permasalahan lainnya adalah kurangnya ketersediaan es untuk kegiatan operasi penangkapan ikan. Hal ini disebabkan terbatasnya pabrik es di Kabupaten Natuna. Minimnya pabrik es dikatakan pula menjadi penyebab nelayan lokal tidak dapat menangkap ikan dalam jumlah besar karena khawatir mutu ikan yang ditangkap tidak dapat dipertahankan dengan jumlah es yang terbatas tersebut.

Permasalahan pada industri pengolahan ikan adalah pengolahan ikan yang dilakukan masih sangat sederhana dan merupakan usaha skala rumah tangga (home industry). Jenis pengolahan ikan yang umum dilakukan berupa ikan asap, kerupuk atom, kerupuk ikan, bethik, bakso ikan, dan abon. Produkproduk ini dapat ditetapkan sebagai produk unggulan perikanan (Triyono dan Ramadona 2018). Pengolahan abon ikan hanya dilakukan ketika menjelang lebaran. Sementara itu, ikan asap dan kerupuk merupakan jenis olahan yang dominan. Bahan baku yang digunakan umumnya adalah ikan tongkol, karena ikan ini merupakan jenis ikan yang paling banyak tertangkap oleh nelayan. Permasalahan lain pada industri pengolahan adalah kapasitas tenaga kerja yang terbatas, bahan baku tepung terigu yang mahal dan belum tersedianya fasilitas untuk pengemasan produk. Permasalahan tenaga kerja untuk pengembangan industri pengolahan di Natuna diantaranya adalah terkait dengan disiplin kerja dari tenaga kerja lokal yang masih rendah. Harga tepung terigu dan bahan kemasan produk sangat mahal, karena masih harus didatangkan dari luar daerah (Jakarta). Diversifikasi produk olahan ikan masih terbatas. Jenis produk olahan ikan di Natuna masih terbatas. Diversifikasi produk pengolahan ikan yang masih terbatas, disebabkan oleh jenis ikan hasil tangkapan yang terbatas dan keterbatasan pengetahuan serta keterampilan sumberdaya manusia dalam pengolahan ikan. Namun, pemerintah Kabupaten Natuna telah memberikan kemudahan kepada pengolah ikan dalam mendapatkan sertifikat halal di Dinas Kesehatan Kabupaten Natuna.

Permasalahan pemasaran ikan Natuna terutama adalah aksesibilitas yang masih terbatas. Hal ini menjadikan nelayan tidak termotivasi untuk meningkatkan hasil tangkapan, karena pada saat hasil tangkapan melimpah juga tidak dapat terserap pasar. Sebagian besar hasil tangkapan dijual di pasar lokal. Pasar ekspor adalah untuk produk ikan demersal dijual dalam bentuk ikan segar serta ikan karang umumnya dijual dalam kondisi segar atau hidup. Produksi hasil olahan ikan dipasarkan di pasar lokal dan beberapa dipasarkan antar daerah atau antar pulau. Pemasaran hasil olahan ikan juga mengandalkan pendatang yang datang ke Kabupaten Natuna. Sebenarnya terbuka peluang pasar yang besar untuk olahan kerupuk, dengan adanya permintaan dari Singapura, namun tidak dapat dipenuhi karena terbatasnya sumberdaya yang dimiliki.

Secara umum peluang dan permasalahan perikanan Natuna seperti dideskripsikan pada Tabel 4. Peluang dan permasalahan ini perlu mendapatkan perhatian dari pemerintah untuk pengembangan perikanan Natuna.

\section{Langkah-langkah Strategis untuk Percepatan Fungsionalisasi SKPT Natuna}

Berdasarkan pemahaman terhadap peluang dan permasalahan seperti yang telah dideskripsikan pada bahasan sebelumnya, maka diperlukan langkah-langkah strategis agar SKPT Natuna dapat beroperasi dan berfungsi sebagaimana yang diharapkan dari tujuan pembangunannya. Perencanaan strategis perlu dilakukan secara integrasi industri perikanan tangkap, pengolahan dan pemasaran.

Industri penangkapan ikan dapat dikembangkan diantaranya adalah pemanfaatan potensi sumberdaya ikan pelagis. Perikanan pelagis dapat dikembangkan melalui realokasi kapal yang lebih besar dari 30GT dari kapal yang sebelumnya dilarang beroperasi dari Laut Jawa bagian Utara ke Perairan Natuna. Pemerintah harus memperkirakan jumlah total kapal nelayan yang diperbolehkan untuk beroperasi di Natuna sesuai dengan kemampuan sumberdaya atau dibatasi sampai dengan 50\% TAC di Natuna. Keterampilan nelayan skala kecil perlu ditingkatkan untuk dapat melakukan penangkapan ikan lebih jauh dari pantai atau di wilayah ZEE untuk mengurangi kemungkinan penangkapan berlebih di perairan dekat 
pantai. Peningkatan keterampilan penting dilakukan dengan strategi memberikan pelatihan dan pendampingan nelayan (Mira et al. 2013). Pengembangan armada penangkapan ikan perlu dikendalikan melalui penyediaan izin yang transparan, pemantauan dan pengaturan jumlah total lisensi, data buku catatan (log book) yang baik untuk pemantauan tangkapan, dan penegakan hukum yang tegas terhadap kapal-kapal yang beroperasi secara ilegal.

Rencana pengembangan usaha SKPT di Natuna saat ini adalah untuk mengintegrasikan nelayan kecil melalui kerjasama dan penjualan ikan kepada PERINDO secara langsung dengan harga yang wajar. SKPT akan membangun 200 ton Integrated Cold Storage (ICS) dan akan membeli ikan secara langsung dari para nelayan kecil di sekitar Natuna, yang rencananya melibatkan 200 nelayan yang ada saat ini (CSF 2017). Pengembangan pasar dan penyerapan hasil tangkapan nelayan merupakan langkah strategis yang perlu dilakukan. Saat ini nelayan tidak termotivasi untuk meningkatkan hasil tangkapannya, karena kesulitan untuk memasarkannya. Hasil wawancara dengan nelayan mendukung hal tersebut, nelayan menga- takan hasil tangkapan yang melimpah pada saat musim ikan sampai tidak terjual. Keberadaan SKPT diharapkan mampu menampung hasil tangkapan nelayan dari dermagadermaga kecil yang ada melalui pengadaan kapal pengumpul, yang akan membawa hasil tangkapan ke SKPT. Selanjutnya hasil tangkapan dapat disimpan di ICS atau dipasarkan ke luar daerah maupun ekspor.

Industri pengolahan ikan di Natuna masih sangat terbatas. Langkah strategis untuk pengembangan industri pengolahan ikan adalah diversifikasi produk. Produksi ikan tongkol yang cukup banyak, selain dijadikan bahan baku untuk produk olahan fillet atau loin beku. Produk beku ini dapat disimpan dalam waktu lama, dan dapat ditujukan untuk pasar luar daerah maupun ekspor. Pengembangan produk ini perlu didukung dengan penambahan fasilitas pabrik es dan fasilitas penyimpanan produk beku (cold storage) di SKPT. Diversifikasi produk olahan lainnya masih dapat dikembangkan, tentu saja harus didukung dengan kebijakan strategis lainnya terkait kemudahan bahan baku dan bahan pengemas produk, peningkatan kapasitas sumber daya manusia, dan faktor pendukung lainnya.

Tabel 4 Peluang dan Permasalahan Perikanan Natuna

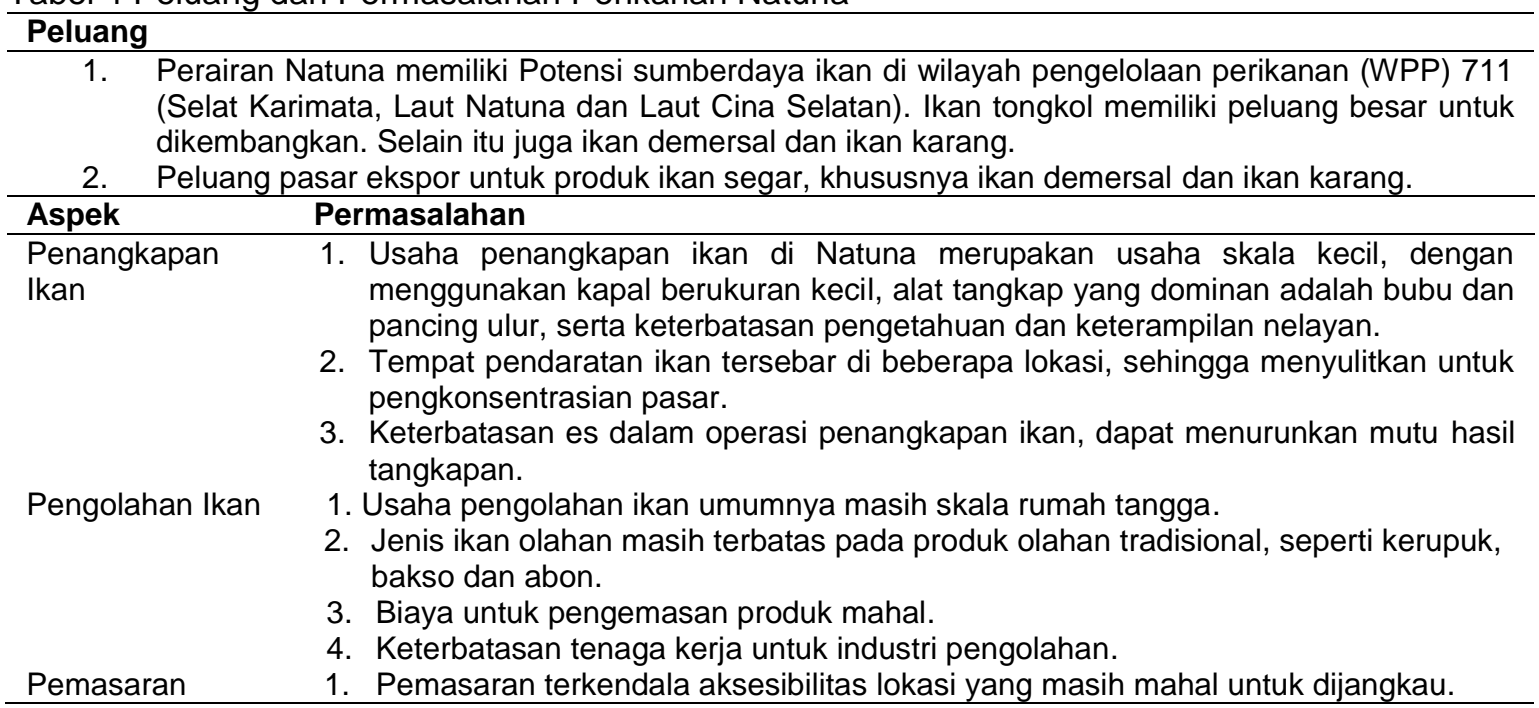

\section{PEMBAHASAN}

Perairan Natuna memiliki potensi sumberdaya ikan yang termasuk di wilayah pengelolaan perikanan (WPP) 711 (Selat Karimata, Laut Natuna dan Laut Cina Selatan). Wilayah perairan ini merupakan wilayah perairan yang subur. Nababan dan Simamora (2012) menyatakan bahwa keberadaan hutan mangrove mendukung kesuburan perairan Laut Natuna. Ekosistem mangrove tumbuh dengan baik di perairan ini karena didukung oleh keberadaan teluk yang menjadi muara banyak sungai. $\mathrm{Hal}$ ini mendukung ketersediaan nutien yang cukup dan substrat yang ideal untuk tumbuh kembangnya mangrove (Muarif 2017). Sekitar Perairan Natuna mengalir beberapa sungai besar beserta anak-anak sungainya seperti Sungai Musi, Sungai Batanghari yang 
mengalir dari arah barat (Pulau Sumatera), sedangkan Sungai Kapuas serta Sungai Sambas dari arah timur (Pulau Kalimantan) yang dapat menambah kesuburan perairan.

Potensi sumberdaya ikan Laut Natuna berdasarkan studi identifikasi potensi sumber daya kelautan dan perikanan Provinsi Kepulauan Riau tahun 2011 yaitu sebesar $504.212,85$ ton per tahun atau sekitar 50\% dari potensi WPP 711 sebesar 1.059 .000 ton per tahun dengan jumlah tangkapan yang diperbolehkan (80\% dari potensi lestari) mencapai 403.370 ton. Pada tahun 2015 produksi ikan sebesar 48.699 ton, maka peluang pengembangan perikanan tangkap masih sangat besar (Ditjen Pengelolaan Ruang Laut, 2015) dalam Pusdatin KKP (2016). Hasil studi CSF (2017) menyatakan bahwa, potensi sumberdaya ikan pelagis besar WPPNRI 711 sebesar 198.994 ton, dengan JTB 159.195 ton. JTB untuk Natuna diperkirakan $50 \%$, yaitu sekitar 79.598 ton. Pemanfaatan saat ini sekitar 0,42 atau sekitar 33.431 ton, maka masih ada potensi yang bisa dikembangkan yaitu sekitar 46.167 ton per tahun. Hal ini tidak jauh berbeda seperti dinyatakan oleh Hidayat et al. (2019), potensi ikan pelagis utamanya adalah ikan cakalang dan tongkol, dengan tingkat pemanfaatan baru sekitar $60 \%$ dari potensi lestari (Hidayat et al. 2019). Sementara potensi ikan demersal berupa ikan kakap merah, kerapu, anggoli, dan manyung. Hal ini juga sesuai dengan hasil penelitian Zulham (2018) yang menyatakan bahwa hasil tangkapan nelayan Natuna pada tahun 2017 terdiri dari ikan kerapu 301,9 ton; kurisi bali 233,1 ton; kakap merah (anggoli) 208,9 ton; kurisi 252 ton; manyung 318,1 ton; gurita 138,5 ton; cumi-cumi 237,9 ton; ikan tongkol dan ikan layang masing-masing 311,2 ton dan 451,7 ton.

Peluang pengembangan armada penangkapan ikan di Kabupaten Natuna masih terbuka. Pembangunan SKPT yang berlokasi di Selat Lampah, diharapkan dapat mempercepat laju perkembangan perikanan di Natuna. SKPT di Selat Lampa direncanakan akan dijadikan sentra dan check point bagi kegiatan perikanan di Natuna. Namun, lokasi ini sangat jauh untuk dijangkau bagi beberapa daerah seperti Serasan Barat, Serasan Timur, dan Subi, sehingga nelayan yang memiliki fishing base pada daerah tersebut akan lebih baik untuk tetap memasarkan hasil tangkapannya ke Pemangkat (CSF 2017).

Nelayan Natuna dengan keterbatasan armada yang dimiliki, beroperasi di sekitar pantai dan mendaratkan hasil tangkapannya di dermaga kecil di sekitar pemukiman penduduk. Dermaga-dermaga kecil banyak ditemui di desa-desa pesisir sebagai tempat labuh kapal penangkapan ikan dan pembongkaran hasil tangkapan (Zulham 2018; Pratama et al. 2020).

Unit armada penangkapan ikan yang digunakan nelayan adalah armada skala kecil. Hasil penelitian CSF (2017) menyatakan bahwa teknologi penangkapan ikan yang digunakan terlihat lamban berkembang. Hal ini disebabkan oleh beberapa faktor, diantaranya yaitu 1) nelayan tidak termotivasi untuk meningkatkan hasil tangkapannya karena keterbatasan pasar; 2) nelayan tidak terbiasa melakukan trip penangkapan dalam waktu yang lama, yaitu terbiasa melakukan one day trip; 3) biaya investasi dan biaya operasional cukup mahal untuk armada berukuran > 10 GT; 4) adanya sosial buffer selain menangkap ikan, yaitu kepemilikan kebun dan adanya pekerjaan sebagai buruh yang dapat dijadikan nelayan lokal sebagai alternatif pekerjaan saat tidak melakukan kegiatan penangkapan ikan.

Langkah-langkah strategis yang dapat dilakukan untuk mempercepat operasionalisasi dan fungsionalisasi SKPT Natuna adalah mendatangkan unit penangkapan ikan dari luar Natuna. Hasil penelitian CSF (2017) menyatakan bahwa Nelayan lokal di Kabupaten Natuna merasa tidak keberatan jika pemerintah mendatangkan nelayan dari luar untuk melakukan kegiatan penangkapan ikan di wilayah perairan Natuna dan memiliki fishing base di Natuna. Namun, pemerintah Kabupaten Natuna perlu memberikan perhatian lebih terhadap kemampuan nelayan lokal dalam melakukan kegiatan penangkapan ikan. Adanya kesenjangan kemampuan dalam mengoperasikan alat penangkap ikan antara nelayan lokal dengan nelayan pendatang yang sangat besar akan dapat memunculkan konflik. Nelayan lokal seringkali merasa tersaingi dengan keberadaan nelayan pendatang (terutama nelayan dari Jawa). Namun nelayan lokal menyatakan bahwa hal tersebut tidak sampai menyebabkan konflik besar asalkan nelayan pendatang tidak mengganggu daerah penangkapan ikan nelayan lokal, misalnya melakukan kegiatan penangkapan dengan menggunakan alat tangkap yang tidak ramah lingkungan.

Pengembangan pasar dan penyerapan hasil tangkapan nelayan merupakan langkah strategis yang perlu dilakukan. Saat ini, nelayan mendaratkan ikannya di banyak dermaga kecil yang tersebar di berbagai tempat di sepanjang pantai Natuna. Nelayan 
dari Serasan Barat, Serasan Timur, dan Subi lebih memilih mendaratkan dan menjual hasil tangkapannya di Pemangkat (Kalimantan). Harga jual yang lebih baik di Pemangkat juga menjadi alasan nelayan lokal yang menjual hasil tangkapan di Pemangkat. Selain pemasaran produk pengolahan ikan, terdapat pula pemasaran ikan segar untuk ikan demersal dan ikan hidup untuk jenis ikan karang yang ditangkap oleh nelayan di Kabupaten Natuna. Harga jual ikan segar utuh ke luar negeri lebih tinggi dibandingkan dengan harga jual olahan ikan secara lokal dan antar daerah atau antar pulau. Hal tersebut menyebabkan pengumpul ikan, khususnya untuk ikan demersal seperti kakap dan anggoli menjual hasil tangkapannya ke pasar luar negeri khusunya ke Singapura.

Tujuan pasar untuk ikan pelagis besar di Natuna adalah pasar lokal, pasar luar daerah dan ekspor. Pasar luar daerah, tujuan khususnya adalah Sumatera (Riau), Jawa (Jakarta), Kalimantan Barat (Pemangkat, Pontianak). Pemasaran memerlukan aksesibilitas dan infrastruktur yang baik. Untuk pemasaran luar daerah memerlukan sarana kapal laut atau kapal udara. Kapal udara telah tersedia fasilitas pelabuhan udara milik Angkatan Udara di Ranai, ada penerbangan langsung ke Jakarta atau lewat Batam. Fasilitas pelabuhan udara umum saat ini juga sudah ada dan sudah operasional. Infrastruktur jalan darat dari pusat-pusat pendaratan ikan menuju Ranai telah tersedia, berupa jalan aspal dengan lebar jalan dan kondisi yang memadai. Untuk fasilitas kapal laut tersedia kapal-kapal penyeberangan.

Langkah strategis untuk pengembangan industri pengolahan ikan adalah diversifikasi produk. Pengembangan industri pengolahan ikan dapat meningkatkan nilai tambah produk dan menyimpan produk dalam jangka waktu yang lebih lama. Hasil penelitian CSF (2017) nilai tambah pada produk olahan tradisional berkisar antara Rp 8.000 sampai dengan $\mathrm{Rp} 13.000$ per kg. Hasil perhitungannya yaitu, harga jual tongkol segar per kg yaitu Rp 10.000; sementara itu harga jual untuk produk olahan dari $1 \mathrm{~kg}$ ikan tongkol (sudah diperhitungkan rendemen), ikan asap $R p$ $21.000 / \mathrm{kg}$, bakso ikan Rp 23.333, dan kerupuk ikan $\mathrm{Rp}$ 18.000. Jika diolah dalam bentuk fillet atau loin, nilai tambahnya diharapkan akan lebih besar. Berbagai program telah dilakukan pemerintah untuk pengembangan industri pengolahan ikan di Natuna. Hasil penelitian Zulham (2018) menyatakan bahwa keberadaan pelaku usaha pengolahan di Natuna, dimulai dari program pemberdayaan masya- rakat "kelompok pengolah dan pemasar" (Poklahsar) pada tahun 2012, yang diharapkan dapat mendorong tumbuhnya industri pengolahan skala komersial di Natuna.

\section{KESIMPULAN}

Percepatan fungsionalisasi SKPT Natuna dapat dilakukan dengan mengoptimalkan potensi sumberdaya ikan yang ada. Sementara itu, fungsionalisasi SKPT Natuna terkendala oleh permasalahan, yaitu usaha penangkapan ikan skala kecil, tempat pendaratan ikan tersebar di beberapa lokasi, terbatasnya ketersediaan es untuk melaut, rendahnya pengetahuan dan keterampilan nelayan, usaha pengolahan ikan umumnya masih skala rumah tangga dan terbatas pada olahan tradisional, terbatasnya kapasitas tenaga kerja di industri pengolahan ikan, mahalnya biaya pengemasan, serta terbatasnya aksesibilitas untuk pemasaran ikan.

Langkah-langkah strategis yang dapat dilakukan untuk percepatan fungsionalisasi SKPT Natuna yaitu perencanaan secara terintegrasi pengembangan industri perikanan tangkap, pengolahan dan pemasaran. Pengembangan industri perikanan tangkap melalui pemanfaatan potensi sumberdaya ikan pelagis, meningkatkan keterampilan nelayan, armada penangkapan dikendalikan dengan perizinan dan pendataan. Pengembangan pasar dan penyerapan hasil tangkapan nelayan perlu didukung penambahan fasilitas pabrik es dan ICS. Industri pengolahan ikan dikembangkan melalui diversifikasi produk olahan yang didukung oleh kemudahan input produksi dan tenaga kerja yang kompeten.

\section{SARAN}

Upaya untuk percepatan fungsionalisasi SKPT perlu dilakukan secara terintegrasi melalui pengembangan armada penangkapan ikan, pembangunan cold storage dan industri pengolahan ikan serta pengembangan akses pasar.

\section{UCAPAN TERIMA KASIH}

Penulis mengucapkan terima kasih kepada Yayasan Strategi Konservasi Indonesia (Conservation Strategy Fund Indonesia/CSF Indonesia) dan Fakultas 
Perikanan dan IImu Kelautan - IPB (Institut Pertanian Bogor) yang mendanai kajian ini.

\section{DAFTAR PUSTAKA}

Anggraeni M, Rustiadi E, Yulianto G. 2020. Peranan Sektor Perikanan Terhadap Perekonomian Kabupaten Natuna. J. Kebijakan Sosek KP. 10(1):11-23. Anwar Y, Nurani TW, Baskoro MS. 2019. Sistem Pengembangan Perikanan Ikan Terbang di Pelabuhan Perikanan Nusantara Tual. IImu dan Teknologi Kelautan Tropis. 11(2): 447-459.

[BPS] Badan Pusat Statistik 2017. Kabupaten Natuna dalam Angka 2017. Natuna: Badan Pusat Statistik.

Caraka RE. 2019. Peran LPDB dan KUMKM Natuna untuk Menjadi Poros Maritim Indonesia. Jurnal BPPK. 12(1):1-19.

[CSF] Conservation Strategy Fund. 2017. Analisis Ekonomi dan Value Chain untuk Mendukung Percepatan Pembangunan Industri Perikanan Nasional: Studi Kawasan Natuna, Bitung dan Mimika. Jakarta: Laporan Kajian.

[DKP] Dinas Kelautan dan Perikanan Kabupaten Natuna. 2019. Laporan Tahunan Dinas Kelautan dan Perikanan Kabupaten Natuna Tahun 2019. Ranai: DKP Kabupaten Natuna.

Fauzan, Abdullah K, Ahmad MZ. 2019. Border Security Problems in the Waters of the Natuna Island: Between National Boundaries and Illegal Fishing. AEGIS. 3(2): 95-114.

Gigentika S, Nurani TW, Wisudo SH, Haluan J. 2017. Sistem Pemanfaatan lkan Tuna di Nusa Tenggara. Marine Fisheries. 8(1): 13-23.

Hastuti. 2018. Scenario Planning Pembangunan Sumber Daya Kelautan di Kabupaten Natuna. Jurnal IImu Administrasi. 5(4): 367-396.

Hidayat EF, Pujiyati S, Suman A, Hestirianoto T. 2019. Pendugaan Daerah Potensi Ikan Pelagis di WPPNRI 711 (Studi Kasus Laut Natuna). Jurnal Pengelolaan Sumberdaya Alam dan Lingkungan. 9(1): 92-96.
Hutapea RYF, Solihin I, Nurani TW. 2017. Peran Pelabuhan Perikanan Samudera Nizam Zachman dalam Mendukung Industri Tuna. Marine Fisheries. 8(2): 187-198.

Hutapea RYF, Solihin I, Nurani TW, Rosalia AA, Putri AS. 2019. Strategi Pengembangan Pelabuhan Perikanan Nizam Zachman dalam Mendukung Industri Perikanan Tuna. Jurnal Teknologi Perikanan dan Kelautan. 10(2): 233-245.

[KKP] Kementerian Kelautan dan Perikanan. 2016. Kelautan dan Perikanan dalam Angka Kabupaten Natuna. Jakarta: KKP.

Maulana RY, Rakhman MA. 2020. Pendekatan Good Governance Dalam Memperkuat Keamanan Perbatasan Negara: Studi di Wilayah Laut Natuna Utara. Jurnal Wacana Politik. 5(1): 71-86.

Mawanto A. 2020. Pengaruh Dukungan Logistik Terpadu di Wilayah Natuna terhadap Kesiapan Operasi KOGABWILHAN I. Jurnal Logistik Indonesia. 4(2): 146-153.

Mira, Solihin A, Tajerin. 2013. Strategi Peningkatan Ekonomi Wilayah Perbatasan Berbasisi Kelautan dan Perikanan (Studi Kasus di Nanusa, Natuna dan Nunukan). Sosiokonsepsia. 18(3): 255-278.

Muarif. 2017. Karakteristik Ekosistem Mangrove di Kawasan Pesisir Kepulauan Natuna Characteristic of Mangrove Ecosystem in Natuna Island Coastal Area. Jurnal Mina Sains. 3(2): 44-49

Nababan B, Simamora K. 2012. Variabilitas Konsentrasi Klorofil-a dan Suhu Permukaan Laut di Perairan Natuna. Jurnal IImu dan Teknologi Kelautan Tropis. 4(1): 121-134.

Nugrohadi IAW, Devi A, Rusydiana AS. 2015. Analisis Tinjauan dan Posisi Daya Saing Perikanan Kabupaten Natuna Melalui Pendekatan LQ (Location Quotient), SSA (Shift Share Analysis) dan RCA (Revealed Comparative Advantage). Jurnal Administrasi dan Manajemen. 5(1): 201-211. 
Nurani TW, Wisudo SH, Wahyuningrum PI, Arhatin RE. 2018. Model Designs of Indonesian Tuna Fishery Management in the Indian Ocean (FMA 573) Using Soft System Methodology Approach. Eqyptian Journal of Aquatic Research. 44: 139144

Pratama GB, Nurani TW, Wahju RI. 2020. Rancang Bangun Sistem Basis Data untuk Menunjang Pengelolaan Perikanan Tuna Cakalang dan Tongkol di Perairan Natuna. Jurnal Akuatika Indonesia. 5(2): 77-85.

Pusat Data, Statistik dan Informasi Kementerian Kelautan dan Perikanan. 2016. Kelautan dan Perikanan dalam Angka Kabupaten Natuna. Kementerian Kelautan dan Perikanan Republika Indonesia.

Putranto GNW, Zid M, Miarsyah M. 2019. Konflik Batas Maritim, Illegal Fishing dan Upaya Pengekannya di Wilayah Laut Natuna antara Indonesia dan China. Jurnal Perikanan dan Kelautan. 9(2):185-193.
Reza M, Nurani TW, Solihin I. 2019. Strategi Pemenuhan Kebutuhan Industri Pengolahan Ikan di Pelabuhan Perikanan Samudera Belawan. Jurnal Teknologi Perikanan dan Kelautan. 10(2): 123-124.

Riyadi RA, Sari DAA. 2019. Pemutakhiran Peta di Kawasan Laut Natuna Utara sebagai Langkah Indonesia Menjadi Poros Maritim Dunia. Belli Ac Pacis. 5(1): 18-31.

Syukhriani S, Nurani TW, John Haluan J. 2018. Model Konseptual Pengembangan Perikanan Tongkol dan Cakalang yang Didaratkan di Kota Bengkulu. Jurnal Teknologi Perikanan dan Kelautan. 9(1): 1-11.

Triyono Ramadona. 2018. Penentuan Produk Unggulan Perikanan dan Pengembangannya di Pulau Terdepan Indonesia (Kasus di Kabupaten Natuna). Jurnal TechnoFish. 2(2): 41-53.

Zulham A. 2018. Penilaian Sosial dalam Membangun Entitas Bisnis Perikanan pada SKPT Selat Lampa. J. Kebijakan Sosek KP. 8(1): 1-12. 